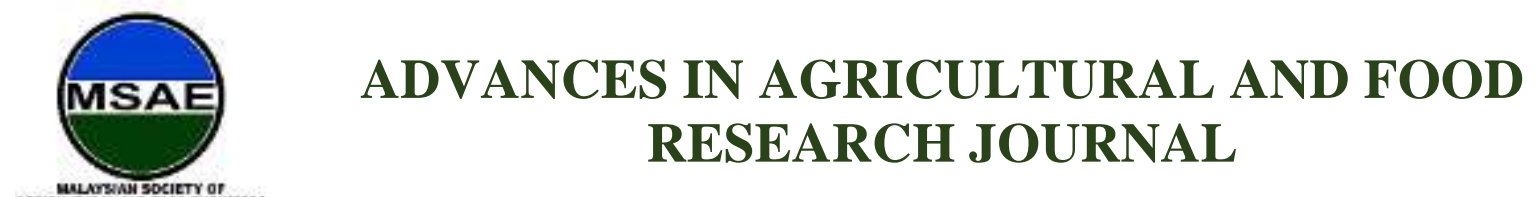

Original Research Article

\title{
Physicochemical, Textural, Thermal Properties of Rice Bran Oil Spread as Alternate Shortening for Bakery Products
}

\author{
Hui Yi Eng ${ }^{1}$, Norazatul Hanim Mohd Rozalli ${ }^{1^{*}}$, Nurul Najihah Ilias ${ }^{1}$ \\ ${ }^{1}$ Food Technology Division, School of Industrial Technology, Universiti Sains Malaysia, 11800 USM, Pulau \\ Pinang, Malaysia. \\ *Corresponding author: Norazatul Hanim Mohd Rozalli, Food Technology Division, School of Industrial \\ Technology, Universiti Sains Malaysia, 11800 USM, Pulau Pinang, Malaysia; norazatulhanim@usm.my
}

Abstract: The rice bran oil (RBO) can form its semisolid spread through solvent fractionation. The rice bran oil spread (RBOS) is proposed to be included in the production of bakery products. This study compares the physicochemical, textural properties, and thermal properties of RBOS with commercial shortening (CS) and rice bran oil (RBO). Spreadability analysis was conducted using a texture analyzer. There was no significant difference $(p>0.05)$ in firmness and work of shear between CS and RBOS. The fatty acid compositions were determined through GC-MS. The major fatty acids in RBOS were palmitic acid, oleic acid, and linoleic acid, similar to those in RBO but significantly ( $p<$ 0.05 ) higher in saturated fatty acid content. RBO contains a high amount of $\gamma$-oryzanol and phytosterols, which is beneficial in solid fat structuring. The quantitation of $\gamma$-oryzanol was performed using the UV-Vis spectrophotometer while the phytosterol content was analyzed using HPLC. There was no significant difference $(p>0.05)$ in $\gamma$-oryzanol between RBO $(1,299.88 \pm 50.97 \mathrm{mg} / 100 \mathrm{~g}$ sample $)$ and $\operatorname{RBOS}(1,201.86 \pm 84.37 \mathrm{mg} / 100 \mathrm{~g}$ sample $)$. However, there was a significant difference $(p<0.05)$ in phytosterols between CS $(4.17 \pm$ $0.26 \mathrm{mg} / 100 \mathrm{~g}$ sample), RBO (247.00 $\pm 0.89 \mathrm{mg} / 100 \mathrm{~g}$ sample) and RBOS (184.16 \pm 0.56 $\mathrm{mg} / 100 \mathrm{~g}$ sample). Besides, thermal analysis of CS and RBOS was carried out using DSC and TGA. The similar textural properties but higher bioactive compounds content make RBOS a suitable choice as alternate shortening for bakery products.

Keywords: Rice bran oil; Spread; Physicochemical; Textural; Thermal

Received: $13^{\text {th }}$ March 2021

Received in revised form: $17^{\text {th }}$ April 2021

Accepted: $5^{\text {th }}$ May 2021

Available Online: $25^{\text {th }}$ May 2021

Citation: Eng, H. Y., Norazatul Hanim, M.R., Nurul Najihah, I. Physicochemical, textural, thermal properties of rice bran oil spread as alternate shortening for bakery products. Adv Agri Food Res J 2021; 2(1): a0000207. https://doi.org/10.36877/aafrj.a0000207 


\section{Introduction}

Rice bran oil (RBO) is one of the by-products of the extraction of rice bran. $\mathrm{RBO}$ is considered one of the superior edible oils compared to other oils because of its ideal fatty acid composition. RBO contains approximately 18-24\% saturated fatty acid (SFA), 40-43\% monounsaturated fatty acid (MUFA), and 31-35\% polyunsaturated fatty acid (PUFA) (Balachandran et al., 2008; Khatoon \& Gopalakrishna, 2004). Besides, RBO contains 4.2\% unsaponifiable contents (Ghosh, 2007), which are higher than other oils, such as mustard seed oil (0.56-1.01\%) (Konukan et al., 2019; Singh, 2018), sunflower oil (0.81\%) (Konukan, et al., 2019), peanut oil (0.98-1.52\%) (Zahran \& Tawfeuk, 2019), rapeseed oil (0.97\%) (Konukan, et al., 2019), olive oil (1.50\%) (Textron, 2011) and others. The important unsaponifiable matters in RBO include $\gamma$-oryzanol, phytosterols, tocopherols, squalene, and fatty alcohols (Ghosh, 2007; Sahu et al., 2018). These unsaponifiable matters in RBO contribute to the hypocholesterolemic properties, reducing low-density lipoprotein and total serum cholesterol in the human body (Lai et al., 2019; Sahu et al., 2018). Besides, antioxidant properties of rice bran were also reported in a few literature (Mingyai et al., 2018; Nagendra Prasad et al., 2011; Wang et al., 2002). Besides protective effects, its smoke point $\left(254^{\circ}\right)$ is high enough to make RBO suitable for cooking and deep frying (Mariod et al., 2014).

Oil fractionation is a processing technique to vary the oil and fat properties, other than interesterification and hydrogenation. The fractionation process has two stages. Firstly, oils and fat are partially crystallized, undergoing gradual cooling to the specific temperature. Then, the solid (stearin) and liquid (olein) fractions were filtered or centrifuged (Kellens et $a l ., 2007)$. Oil is being fractionated to become few fractions of solid or semisolid state with various melting points and solid fat content. Based on the procedures and separation methods, there are three types of fractionation in the industry: detergent fractionation, dry fractionation, and solvent fractionation (Hasibuan et al., 2018). The detergent fractionation is a cooling crystallization by batch or continuous with the aid of surfactants and fractions separation (Hasibuan et al., 2018). Dry fractionation is a thermomechanical separation process, while solvent fractionation is partial crystallization due to the partial solubility into the specific solvent (Jääskeläinen et al., 2017; Zaliha et al., 2004). Fractionation of rice bran oil was also being studied and reported in works of literature (Bakota et al., 2013; Lee et al., 2007; Yu et $a l ., 2006)$. Rice bran oil was reported to be fractionated with the aid of acetone under a temperature below $0^{\circ} \mathrm{C}$. Bakota et al. (2014) showed that rice bran oil spreads, a product from solvent fractionation of RBO, had been successfully incorporated into baked goods with high 
acceptability in a sensory test. Other forms of rice bran oil spread reported to be used as an additive in cake, doughnuts, cookies, muffins, and piecrusts (Shaik et al., 2018).

In Malaysia, rice bran is considered as underutilized as the lipids in crude rice bran are easily decomposed due to lipase activity (Shafie \& Norhaizan, 2017). This causes rice bran products to be less interested in consumers. As mentioned, rice bran oil spread can be used as an alternate shortening in bakery products. Shortening is usually used to coat the gluten strands and reduce a rigid matrix in bread. It helps to shorten the gluten, creating a tender bread product (Jones, 2016). However, shortening contains $100 \%$ of fat, neither protein nor carbohydrates. Besides, shortening is made by hydrogenation of vegetable oil, producing run-flat (Bussing, 2019; Jones, 2016). In contrast with rice bran oil, trans-fat in shortening helps raise low-density lipoprotein (LDL) cholesterol, increasing the risk of getting cardiovascular diseases (Iqbal, 2014).

This study aims to study the characterization of rice bran oil spread compared to commercial shortening and rice bran oil. The evaluated characteristics included physicochemical, textural, and thermal properties before incorporating rice bran oil spread in the baked goods.

\section{Materials and Methods}

\subsection{Samples and Reagents}

Commercial rice bran oil (RBO) was purchased from Greenapple Organic Sdn. Bhd, imported from India. Farmland commercial shortening (CS) that 360 Horizon Sdn Bhd manufactures purchased from Tesco Extra, Gelugor, Pulau Pinang. Stigmasterol, campesterol, and $\beta$-sitosterol were obtained from Merck (Germany). All other solvents and chemicals were purchased from R\&M chemicals unless otherwise stated and were of HPLC grade or AR grade for solvents.

\subsection{Solvent Fractionation of Rice Bran Oil (RBO)}

Solvent fractionation of rice bran oil was carried according to Bakota et al. (2014). $\mathrm{RBO}$ was brought to room temperature before fractionation. Acetone was chilled in the freezer at $-20^{\circ} \mathrm{C}$ for two hours before fractionation in a stoppered Erlenmeyer flask. Eighty grams of RBO was added to a beaker with $200 \mathrm{~mL}$ acetone, and the mixture was stirred briefly. The beaker containing the mixture was stored at $-20^{\circ} \mathrm{C}$ for 1 hour. Then, the cold slurry was filtered through Whatman No. 3 filter paper using the Buchner funnel. The slurry 
was dried in a desiccator for 24 hours and scrapped to collect the final product, rice bran oil spread (RBOS).

\subsection{Physicochemical Properties}

\subsubsection{Determination of $\gamma$-oryzanol}

According to Sawadikiat and Hongsprabhas (2014), a 10mg aliquot of sample was weighed into a $10-\mathrm{mL}$ volumetric flask. Hexane was added to dissolve the sample and adjusted to the volume. The absorbance of each sample was measured at the wavelength of $314 \mathrm{~nm}$ using a UV-Vis spectrophotometer (Model UVmini-1240, Shimadzu, Japan). The concentration of $\gamma$-oryzanol in each sample was calculated using Equation 1 as shown below:

$$
\text { Conc }=\frac{\mathrm{A} \times \mathrm{V} \times 1,000}{\mathrm{~m} \times 358.9}
$$

Where:

$\mathrm{A}=$ absorbance of the sample at $314 \mathrm{~nm}$ in hexane solution,

$\mathrm{V}=$ volume of hexane used in millilitre,

$\mathrm{m}=$ mass of sample in gram.

$358.9=$ mass extinction coefficient of $\gamma$-oryzanol.

\subsubsection{Determination of phytosterols}

Stigmasterol, campesterol, and $\beta$-sitosterol in the samples were detected and determined according to Balachandran et al. (2008).

One gram of sample was added in a $250-\mathrm{mL}$ round-bottom flask with $100 \mathrm{~mL} 0.8 \mathrm{M}$ ethanolic potassium hydroxide $(\mathrm{KOH})$. The mixture was heated at $80^{\circ} \mathrm{C}$ for $30 \mathrm{~min}$. After heating, the mixture was placed in a $250-\mathrm{mL}$ separatory funnel with $100 \mathrm{~mL}$ of diethyl ether and shaken. The mixture was then washed three times with $50 \mathrm{~mL}$ of distilled water to remove the water-soluble compounds. The ether layer containing the targeted unsaponifiable compounds was concentrated using a rotary evaporator at room temperature with a pressure of $400 \mathrm{MPa}$. Each flask was flushed with nitrogen gas, and the lipid residues containing the sterols were dissolved in $1 \mathrm{~mL}$ absolute ethanol. The mixture was filtered through a $0.22 \mu \mathrm{m}$ Millipore filter and stored in an amber bottle. The samples were stored in the chiller at $4^{\circ} \mathrm{C}$ before being injected into HPLC.

The standards and samples were injected into RP-HPLC, which consisted of an HPLC pump (Model 515, Waters, United States) and a dual absorbance detector (Model 2487, United States). A $10-\mu \mathrm{L}$ aliquot of standard or sample was manually injected in the mobile 
phase, which consisted of a mixture of methanol: water $(96.5: 3.5, \mathrm{v} / \mathrm{v})$, at a flow rate of 1.2 $\mathrm{mL} / \mathrm{min}$, passing through a C18 column (Zobrax Eclipse Plus, Agilent, United States) with a length of $150 \mathrm{~mm}$, particle size of $3.5 \mu \mathrm{m}$, and inner diameter of $4.6 \mathrm{~mm}$. The sterol compounds were detected at the wavelength of $206 \mathrm{~nm}$. The peak was identified by comparing the retention times of standard solutions and confirmed with characteristic spectra using the UV-Vis detector.

\subsubsection{Determination of fatty acid composition}

The fatty acid composition of samples was determined according to Bouarroudj et al. (2016) with slight modification.

A 0.5-g aliquot of sample was weighed and shaken with $5 \mathrm{~mL}$ of hexane and $0.5 \mathrm{~mL}$ of $2 \mathrm{~N}$ methanolic potassium hydroxide $(\mathrm{KOH})$. The mixture was stirred for $30 \mathrm{~s}$ and centrifuged at 3,000 rpm for $5 \mathrm{~min}$. Then, $100 \mu \mathrm{L}$ of supernatant was removed and mixed with $1 \mathrm{~mL}$ of hexane. The mixture was filtered through a $0.22 \mu \mathrm{m}$ Millipore filter and stored in an amber bottle. The samples were stored in the chiller at $4{ }^{\circ} \mathrm{C}$ before being injected into GC-MS.

Fatty acid methyl esters (FAMEs) were analyzed on GC-MS (Model QP 2010, Shimadzu, Japan). A capillary column (BPX70, SGE Analytical Science, United Kingdom) with a length of 30 meters, an inner diameter of $0.25 \mathrm{~mm}$, and film thickness of $0.25 \mu \mathrm{m}$ was used to separate the FAMEs compounds. A 1- $\mu \mathrm{L}$ aliquot of the FAME sample was injected with an inlet temperature of $230^{\circ} \mathrm{C}$. The split mode was $1: 50$, and the helium gas flow was $1.03 \mathrm{~mL} / \mathrm{min}$. The initial temperature of $\mathrm{GC}$ oven was set at $50^{\circ} \mathrm{C}$, held for $2 \mathrm{~min}$, a ramp in temperature of $4^{\circ} \mathrm{C}$ per min to $170^{\circ} \mathrm{C}$ held for $5 \mathrm{~min}$, then a ramp in temperature of $2^{\circ} \mathrm{C}$ per min to $220^{\circ} \mathrm{C}$ held for $10 \mathrm{~min}$. The solvent was cut off for $1.5 \mathrm{~min}$ before MS acquisition began. The transfer line from GC column to MS was set at $230^{\circ} \mathrm{C}$ and the source $200^{\circ} \mathrm{C}$. Source fragmentation was done with a scan range of $29 \mathrm{~m} / \mathrm{z}$ to $550 \mathrm{~m} / \mathrm{z}$. The peaks were identified and compared by relating them to recognized standards.

\subsection{Textural Properties}

\subsubsection{Spreadability test}

A spreadability test was carried out using a texture analyzer (Model TA XT. Plus C, Stable Micro Systems, United Kingdom) equipped with TTC Spreadability Rig and a 30-kg load cell. The spreadability accessory consists of a set of matched male and female Perspex $45^{\circ}$ cones. Each sample was placed in a female cone and pressed down using a spatula to 
eliminate air pockets. The female cone containing the sample was inserted into the female cone sample holder while the male cone was attached to the load cell. The sample was being penetrated by a male cone at the test speed of $3.0 \mathrm{~mm} / \mathrm{s}$ and withdrawn at the post-test speed of $10 \mathrm{~mm} / \mathrm{s}$ after the cone reached the specific penetration depth, causing the sample to be squeezed out. Force-time graphs of the samples were recorded. Each value of firmness (g) and work of shear $(\mathrm{g} \cdot \mathrm{sec})$ were calculated by the Exponent 32 software (Stable Micro Systems, United Kingdom).

\subsection{Thermal Properties}

Differential scanning calorimetry (DSC) techniques and thermogravimetric analysis (TGA) were conducted to investigate the thermal properties of CS and RBOS. RBO was not included in the thermal analysis due to its liquid form. As both CS and RBOS were solid, it is comparable in their melting point and thermal stability.

\subsubsection{Differential scanning calorimetry (DSC)}

DSC test was carried out using the Q200 model (TA instrument, Australia) equipped with a gas controller (Model GC10, Mettler Toledo, Malaysia). The reference was an empty, hermetically sealed aluminum pan. The samples were weighed to $5 \pm 1 \mathrm{mg}$ and hermetically sealed in an aluminum pan. Dry nitrogen gas with $99.99 \%$ purity was purged at $50 \mathrm{~mL} / \mathrm{min}$. Heating was done at $10^{\circ} \mathrm{C} / \mathrm{min}$ from -50 to $10^{\circ} \mathrm{C}$. The results were analyzed using Universal V4.7A TA Instruments software.

\subsubsection{Thermogravimetric analysis (TGA)}

TGA was performed by using the TGA instrument (Mettler Toledo, Malaysia). Approximately 5-10 mg of sample was weighed and placed in a ceramic crucible. The reference was an empty ceramic crucible. The thermal decomposition of each sample was monitored in an airstream at $10^{\circ} \mathrm{C} / \mathrm{min}$ in the temperature range between 30 to $800^{\circ} \mathrm{C}$. The results were analyzed using STARe TGA Evaluation software (Mettler Toledo, Malaysia). The first derivate (DTG) was calculated.

\subsection{Statistical Analysis}

All the tests were performed in triplicate. Results were shown in the form of mean \pm standard deviation. For the variance homogeneity of the results, a one-way analysis of variance (ANOVA) with Tukey's test was applied using SPSS Statistics ver. 27 software (IBM, United States) at the significance level $p<0.05$. 


\section{Results}

\subsection{Physicochemical Properties}

Table 1 showed the quantitation of $\gamma$-oryzanol in three samples. Analysis of variance (ANOVA) showed that there was no significant difference $(p>0.05)$ for the concentration of $\gamma$-oryzanol between RBO and RBOS. The amount of $\gamma$-oryzanol was within the range of 1,201.86-1,299.88 mg/ $100 \mathrm{~g}$ sample. On the other side, $\gamma$-oryzanol was not detected in CS.

Table 1. Quantitation of $\gamma$-oryzanol in each sample.

\begin{tabular}{cc}
\hline Samples $^{1}$ & $\boldsymbol{\gamma}$-oryzanol (mg/ 100 g sample) \\
\hline CS & N.D. ${ }^{2}$ \\
RBO & $1,299.88 \pm 50.97^{\text {a. } 3}$ \\
RBOS & $1,201.86 \pm 84.37^{\mathrm{a}}$ \\
\hline
\end{tabular}

All values are expressed as mean value \pm standard deviation. ${ }^{1} \mathrm{CS}=$ commercial shortening; $\mathrm{RBO}=$ commercial rice bran oil; RBOS = rice bran oil spread. ${ }^{2}$ N.D. represents not detected. ${ }^{3}$ Different alphabets in the same column denoted the significance difference $(p<0.05)$.

Table 2 showed the quantitation of phytosterols in each sample. CS has the least amount of phytosterols. Campesterol and stigmasterol were detected in CS, but $\beta$-sitosterol was not detected. From the table, there were no significant differences $(p>0.05)$ for campesterol and stigmasterol but significant differences $(p<0.05)$ for $\beta$-sitosterol and total phytosterol between RBO and RBOS. Overall, RBO (247.00 $\pm 0.89 \mathrm{mg} / 100 \mathrm{~g}$ sample) has higher total phytosterols concentration than RBOS $(184.16 \pm 0.56 \mathrm{mg} / 100 \mathrm{~g}$ sample $)$ and CS $(4.17 \pm 0.26 \mathrm{mg} / 100 \mathrm{~g}$ sample) .

Table 2. Quantitation of phytosterols in each sample.

\begin{tabular}{ccccc}
\hline Samples $^{1}$ & \multicolumn{3}{c}{ Phytosterols (mg/ 100 g sample) } \\
\cline { 2 - 5 } & Campesterol & Stigmasterol & $\beta$-sitosterol & Total \\
\hline CS & $2.50 \pm 0.17^{\mathrm{b} .2}$ & $1.66 \pm 0.43^{\mathrm{b}}$ & N.D. $^{3}$ & $4.17 \pm 0.26^{\mathrm{c}}$ \\
RBO & $56.94 \pm 3.64^{\mathrm{a}}$ & $31.53 \pm 3.43^{\mathrm{a}}$ & $158.53 \pm 8.02^{\mathrm{a}}$ & $247.00 \pm 0.89^{\mathrm{a}}$ \\
RBOS & $46.24 \pm 7.97^{\mathrm{a}}$ & $20.04 \pm 2.12^{\mathrm{a}}$ & $117.87 \pm 5.30^{\mathrm{b}}$ & $184.16 \pm 0.56^{\mathrm{b}}$ \\
\hline
\end{tabular}

All values are expressed as mean value \pm standard deviation. ${ }^{1} \mathrm{CS}=$ commercial shortening; $\mathrm{RBO}=$ commercial rice bran oil; RBOS = rice bran oil spread. ${ }^{2}$ Different alphabets in the same column denoted the significance difference $(p<0.05) .{ }^{3}$ N.D. represents not detected.

The fatty acid composition of each sample was shown in Table 3. From the table, the dominant fatty acids in CS were palmitic acid (51.49 $\pm 0.08 \%)$ and elaidic acid (34.31 \pm $0.03 \%)$. Other minor fatty acid detected in CS were arachidic acid $(0.28 \pm 0.06 \%)$, myristic acid $(0.78 \pm 0.64 \%)$, stearic acid $(5.05 \pm 0.19 \%)$ and linoleic acid $(7.04 \pm 0.02 \%)$. 
There were three dominant fatty acids detected in RBO and RBOS, which were palmitic acid $(19.61 \pm 0.08 \% ; 28.87 \pm 0.28 \%)$, oleic acid $(45.25 \pm 0.12 \% ; 38.32 \pm 0.33 \%)$ and linoleic acid $(30.74 \pm 0.24 \% ; 25.11 \pm 0.60 \%)$. Other minor fatty acids detected in RBO were linolenic acid $(0.71 \pm 0.01 \%)$, arachidic acid $(0.84 \pm 0.01 \%)$ and stearic acid $(2.09 \pm$ $0.10 \%)$. On the other hands, other minor fatty acids detected in RBOS were behenic acid $(0.25 \pm 0.35 \%)$, linolenic acid $(0.58 \pm 0.03 \%)$, lignoceric acid $(1.06 \pm 0.01 \%)$, arachidic acid $(1.46 \pm 0.03 \%)$, and stearic acid $(3.92 \pm 0.43 \%)$. Overall, CS has significantly $(p<0.05)$ highest amount of SFA $(57.59 \pm 0.28 \%)$ but significantly $(p<0.05)$ least amount of PUFA $(7.04 \pm 0.02 \%)$. RBO has significantly highest amount of MUFA $(45.25 \pm 0.11 \%)$.

Table 3. Fatty acid composition of each sample.

\begin{tabular}{|c|c|c|c|c|c|}
\hline \multirow[t]{2}{*}{ Fatty acid } & \multirow{2}{*}{$\begin{array}{l}\text { Carbon } \\
\text { number }\end{array}$} & \multirow[t]{2}{*}{ Group $^{4}$} & \multicolumn{3}{|c|}{ Relative abundance of the sample $(\%)^{1}$} \\
\hline & & & CS & $\mathrm{RBO}$ & RBOS \\
\hline Myristic acid & $\mathrm{C} 14: 0$ & SFA & $0.78 \pm 0.64^{\text {A. } 2}$ & N.D. & N.D. \\
\hline Palmitic acid & $\mathrm{C} 16: 0$ & SFA & $51.49 \pm 0.08^{\mathrm{A}}$ & $19.61 \pm 0.08^{C}$ & $28.87 \pm 0.28^{\mathrm{B}}$ \\
\hline Stearic acid & C18:0 & SFA & $5.05 \pm 0.19^{\mathrm{A}}$ & $2.09 \pm 0.10^{\mathrm{B}}$ & $3.92 \pm 0.43^{\mathrm{A}}$ \\
\hline Oleic acid & C18:1 & MUFA & N.D. ${ }^{3}$ & $45.25 \pm 0.12^{\mathrm{A}}$ & $38.32 \pm 0.33^{\mathrm{B}}$ \\
\hline Elaidic acid & $\begin{array}{l}\text { C18:1 } \\
\text { (trans) }\end{array}$ & MUFA & $34.31 \pm 0.03^{\mathrm{A}}$ & N.D. & N.D. \\
\hline Linoleic acid & $\mathrm{C} 18: 2$ & PUFA & $7.04 \pm 0.02^{\mathrm{C}}$ & $30.74 \pm 0.24^{\mathrm{A}}$ & $25.11 \pm 0.60^{\mathrm{B}}$ \\
\hline Linolenic acid & C18:3 & PUFA & N.D. & $0.71 \pm 0.01^{\mathrm{A}}$ & $0.58 \pm 0.03^{\mathrm{B}}$ \\
\hline Arachidic acid & C20:0 & SFA & $0.28 \pm 0.06^{\mathrm{C}}$ & $0.84 \pm 0.01^{\mathrm{B}}$ & $1.46 \pm 0.03^{\mathrm{A}}$ \\
\hline Arachidonic acid & $\mathrm{C} 20: 4$ & PUFA & N.D. & N.D. & N.D. \\
\hline Behenic acid & $\mathrm{C} 22: 0$ & SFA & N.D. & N.D. & $0.25 \pm 0.35^{\mathrm{A}}$ \\
\hline Erucic acid & $\mathrm{C} 22: 1$ & MUFA & N.D. & N.D. & N.D. \\
\hline Lignoceric acid & $\mathrm{C} 24: 0$ & SFA & N.D. & N.D. & $1.06 \pm 0.01^{\mathrm{A}}$ \\
\hline SFA & & & $57.59 \pm 0.28^{\mathrm{Aa}}$ & $22.53 \pm 0.18^{\mathrm{Cc}}$ & $35.55 \pm 0.33^{\mathrm{Bb}}$ \\
\hline MUFA & & & $34.31 \pm 0.03^{\mathrm{Cb}}$ & $45.25 \pm 0.11^{\mathrm{Aa}}$ & $38.32 \pm 0.33^{\mathrm{Ba}}$ \\
\hline PUFA & & & $7.04 \pm 0.02^{\mathrm{Cc}}$ & $31.45 \pm 0.23^{\mathrm{Ab}}$ & $25.69 \pm 0.63^{\mathrm{Bc}}$ \\
\hline
\end{tabular}

All values are expressed as mean value \pm standard deviation. ${ }^{1} \mathrm{CS}=$ commercial shortening; $\mathrm{RBO}=$ commercial rice bran oil; $\mathrm{RBOS}=$ rice bran oil spread. ${ }^{2}$ Different alphabets in the same column and row denoted the significance difference $(p<0.05) .{ }^{3}$ N.D. represents not detected. ${ }^{4}$ SFA: saturated fatty acid; MUFA: monounsaturated fatty acid; PUFA: polyunsaturated fatty acid.

\subsection{Textural Properties}

Table 4 showed the spreadability of the CS and RBOS sample. Firmness is defined as the force penetrated at the maximum depth, while shear work is a good indicator of spreadability. The work of shear, which is the area under the positive curve, is also known as 
the total force amount needed to carry out the shearing process. The difference in firmness and work of shear results for both samples were not significantly $(p>0.05)$ significant. The firmness of samples was within the range of 1,226.66-1,256.32 g, while shear work was within the range of 1,022.68-1,099.60 g. sec.

Table 4. Spreadability value of each sample.

\begin{tabular}{ccc}
\hline Samples $^{1}$ & Firmness $^{\mathbf{1}}$ (g) & Work of shear $(\mathbf{g} \cdot \mathbf{s e c})$ \\
\hline CS & $1,226.66 \pm 44.03^{\mathrm{a} .2}$ & $1,022.68 \pm 18.72^{\mathrm{a}}$ \\
RBOS & $1,256.32 \pm 127.98^{\mathrm{a}}$ & $1,099.60 \pm 82.00^{\mathrm{a}}$ \\
\hline
\end{tabular}

All values are expressed as mean value \pm standard deviation. ${ }^{1} \mathrm{CS}=$ commercial shortening; $\mathrm{RBOS}=$ rice bran oil spread. ${ }^{2}$ Same alphabets in the same column denoted the non-significance difference $(p>0.05)$.

\subsection{Thermal Properties}

DSC thermogram of CS and RBOS were shown in Figure 1. Mild and wide endothermic peaks were observed in both CS and RBOS melting curves. The melting curve of CS was started approximately from $-8.43^{\circ} \mathrm{C}$ to $55.42^{\circ} \mathrm{C}$ while the melting curve of RBOS was in the range of temperature from $-23.08^{\circ} \mathrm{C}$ to $50.76^{\circ} \mathrm{C}$. In the thermogram of $\mathrm{CS}$, there were three sharp peaks observed at the melting curve, which were approximately $4.90^{\circ} \mathrm{C}$, $9.91^{\circ} \mathrm{C}$, and $47.76^{\circ} \mathrm{C}$. On the contrary, for the RBOS, one sharp peak associated with few irregulars, shoulder endotherms were noticed at the melting curve. The sharp peak was at the maximum temperature of $42.25^{\circ} \mathrm{C}$. The difference in melting enthalpy for both samples was significantly $(p<0.05)$ significant.

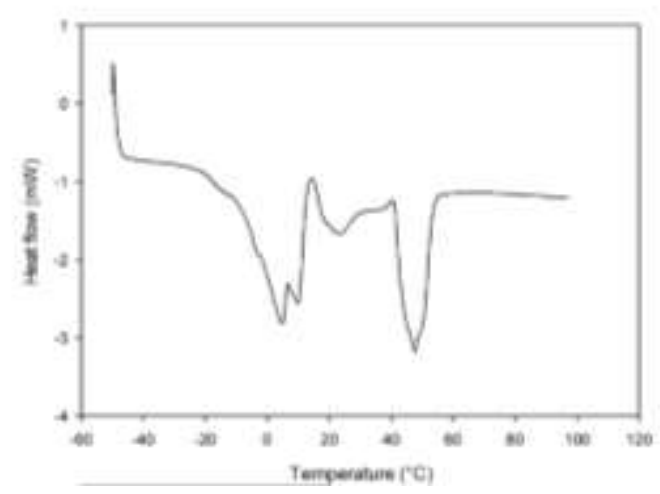

(a)

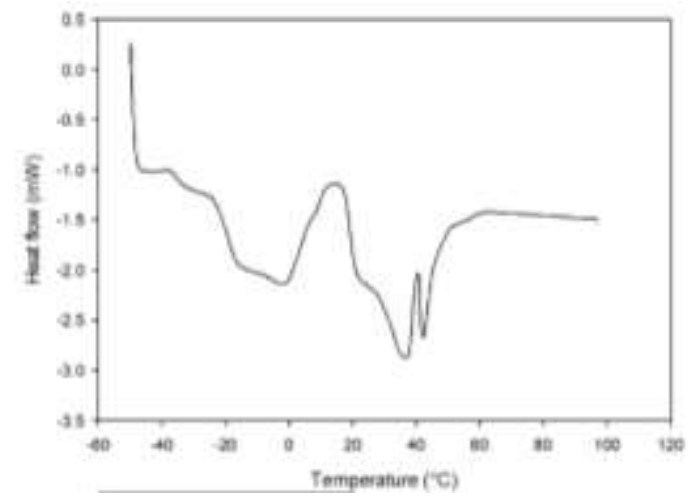

(b)

Figure 1. DSC thermogram: (a) CS; (b) RBOS. 
Table 5. Melting profile of CS and RBOS.

\begin{tabular}{cccccc}
\hline Samples $^{\mathbf{1}}$ & $\mathbf{T}_{\mathbf{o n}}{ }^{2}\left({ }^{\circ} \mathbf{C}\right)$ & $\mathbf{T}_{\text {off }}\left({ }^{\circ} \mathbf{C}\right)$ & $\mathbf{T}_{\mathbf{r}}\left({ }^{\circ} \mathbf{C}\right)$ & $\mathbf{T}_{\mathbf{p}}\left({ }^{\circ} \mathbf{C}\right)$ & $\Delta \mathbf{H}(\mathbf{J} / \mathbf{g})$ \\
\hline CS & -8.43 & 55.42 & 63.85 & 47.76 & 44.65 \\
RBOS & -23.08 & 50.76 & 73.84 & 42.45 & 57.91 \\
\hline
\end{tabular}

${ }^{1} \mathrm{CS}=$ commercial shortening; RBOS = rice bran oil spread. ${ }^{2} \mathrm{~T}_{\mathrm{on}}$ : onset temperature; $\mathrm{T}_{\mathrm{off}}$ : offset temperature; $\mathrm{T}_{\mathrm{r}}$ : temperature range; $\mathrm{T}_{\mathrm{p}}$ : peak temperature; $\Delta \mathrm{H}$ : melting enthalpy.

On the other hand, tested temperatures of CS and RBOS were shown in Table 6. The difference in onset and peak temperature results in both samples were not significant $(p>$ 0.05) important. The onset temperature of samples was within the range of $389.02-393.20^{\circ} \mathrm{C}$, while the peak temperature was within the range of $420.23-421.01^{\circ} \mathrm{C}$. Single-phase decomposition was observed in Figure 2.

Table 6. The temperature of each sample in TGA.

\begin{tabular}{ccc}
\hline Samples $^{\mathbf{1}}$ & $\mathbf{T}_{\text {on }}{ }^{3}\left({ }^{\circ} \mathbf{C}\right)$ & $\mathbf{T}_{\text {peak }}\left({ }^{\circ} \mathbf{C}\right)$ \\
\hline CS & $393.20 \pm 0.05^{\text {a. } 2}$ & $421.01 \pm 1.05^{\text {a }}$ \\
RBOS & $389.02 \pm 5.35^{\text {a }}$ & $420.23 \pm 2.75^{\text {a }}$ \\
\hline
\end{tabular}

All values are expressed as mean value \pm standard deviation. ${ }^{1} \mathrm{CS}=$ commercial shortening; $\mathrm{RBOS}=$ rice bran oil spread. ${ }^{2}$ Same alphabets in the same column denoted the non-significance difference $(p>0.05) .{ }^{3} \mathrm{~T}_{\text {on }}$ : onset temperature; $\mathrm{T}_{\text {peak }}$ : peak temperature.

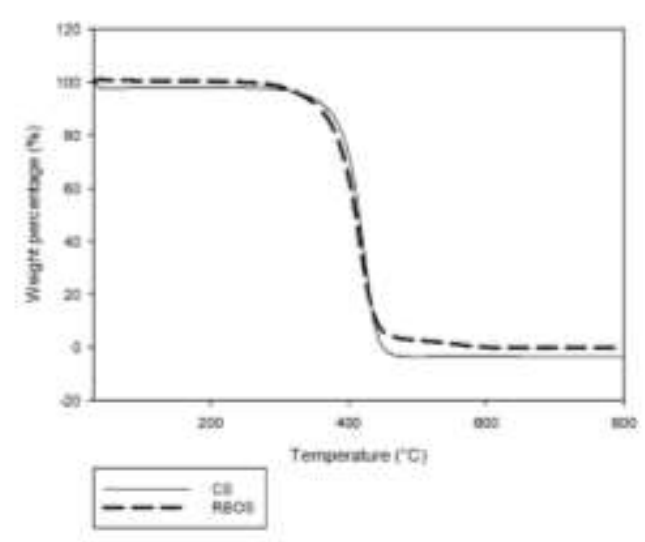

(a)

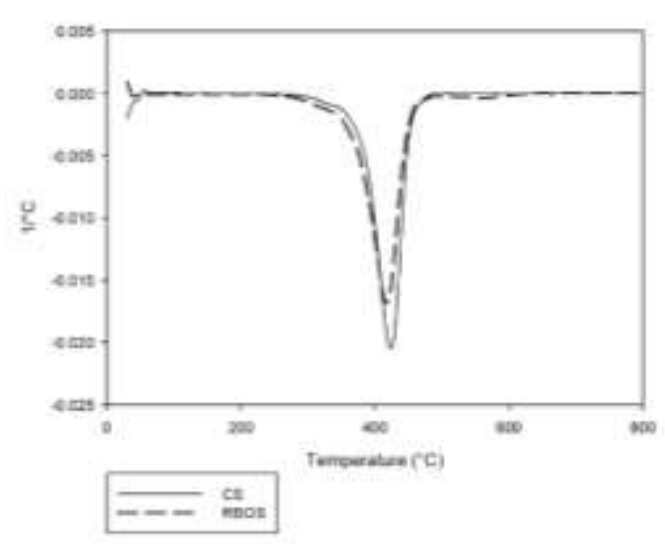

(b)

Figure 2. (a) TGA thermogram; (b) DTG graph for CS and RBOS. The solid line is represented as CS while the dotted line is represented as RBOS.

\section{Discussion}

\subsection{Physicochemical Properties}

The $\gamma$-oryzanol is a distinct compound that physiologically present in rice (Oryza sativa). Oryzanol is not a single compound but a mixture including ferulic acid esters, such 
as $\beta$-sitosterol ferulate, campesteryl ferulate, cycloartenyl ferulate, 24-methylene cycloartenol ferulate, and others (Figure 3) (Patel \& Naik, 2004; Srikaeo, 2014). Oryzanol helps decrease plasma cholesterol levels (Francisqueti et al., 2018; Wang et al., 2015) and aggregation of platelet (Wong et al., 2016). Besides, it shows antioxidant properties by scavenging free radicals and control inflammatory diseases (Panchal et al., 2017; Xu \& Godber, 2001).

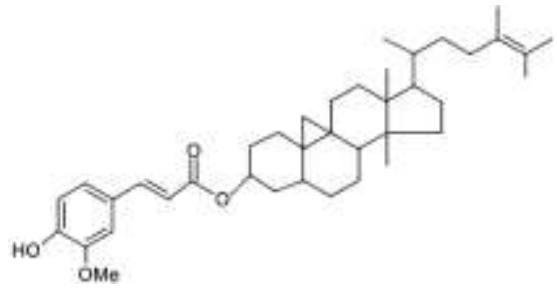

(a)

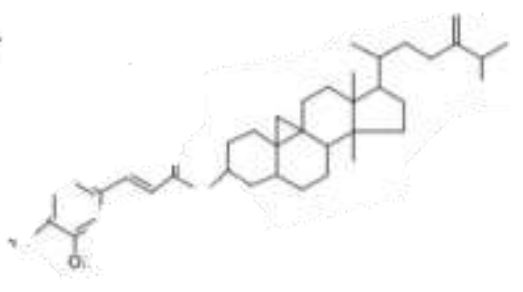

(b)

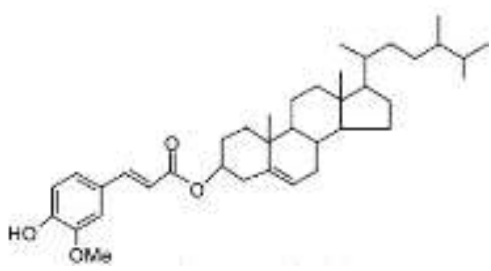

(c)

Figure 3. Dominant components of $\gamma$-oryzanol (Srikaeo, 2014): (a) Cycloartenyl ferulate; (b) 24-Methylene cycloartanyl ferulate; (c) Campesteryl ferulate.

In the present study, UV-spectrophotometry was used to detect total $\gamma$-oryzanol content due to its simplicity and shorter testing period compared to HPLC (Bhatnagar et al., 2014; Pungseeklao et al., 2016). On the other hand, $\gamma$-oryzanol in RBO and RBOS was detected in the range of 1,201.86-1,299.88 mg/ $100 \mathrm{~g}$ sample. This result is in accordance with other studies (Heidtmann-Bemvenuti et al., 2012; Khatoon \& Gopalakrishna, 2004; Sawadikiat \& Hongsprabhas, 2014).

Table 7. Detection and quantitation of $\gamma$-oryzanol in rice bran and its oil using UV-Vis spectrophotometer.

\begin{tabular}{|c|c|c|}
\hline Sample & $\begin{array}{l}\text { Concentration }(\mathrm{mg} / \mathrm{100g} \\
\text { sample })\end{array}$ & Reference \\
\hline Rice bran & $150-1,398$ & (Heidtmann-Bemvenuti et al., 2012) \\
\hline Rice bran oil & $\begin{array}{l}\text { Brown rice: } 1,070-1,430 \\
\text { Milled rice: } 450-630\end{array}$ & (Khatoon \& Gopalakrishna, 2004) \\
\hline Rice bran oil & $304.43-716.46$ & (Pungseeklao et al., 2016) \\
\hline Rice bran oil & $\begin{array}{l}\text { Crude oil: 1,599-1,666 } \\
\text { Refined oil: 933-960 }\end{array}$ & (Sawadikiat \& Hongsprabhas, 2014) \\
\hline
\end{tabular}


On the contrary, most $\gamma$-oryzanol and phytosterol compounds could not be found in CS because they are made from $100 \%$ fat and contain very few bioactive compounds (Jones, 2016).

Similar to $\gamma$-oryzanol, phytosterols also help reduce serum cholesterol concentration in the human body (Özdestan et al., 2014; Vissers et al., 2000; Tolve et al., 2020). Campesterol, stigmasterol, and $\beta$-sitosterol are the dominant phytosterols in rice bran (Figure 4). The current study found that the detected phytosterol in RBO and RBOS were lesser than those recorded in other literature works (Table 8). Commonly, phytosterols were detected and measured by gas chromatography (GC). Nevertheless, the preparation of samples before GC injection includes saponification, extraction, derivatization, and time-consuming others (Lagarda et al., 2006; Plante et al., 2011). Hence, a more straightforward HPLC method was used in the study.

Similar to unsaturated fatty acids and cholesterol, phytosterols are easy to be oxidized due to the presence of steroid rings in phytosterols that are susceptible to autoxidation (Lin et al., 2019; Tolve et al., 2020). Therefore, it was believed that some phytosterols were oxidized during the sample preparation that contributed to the low detected concentration.

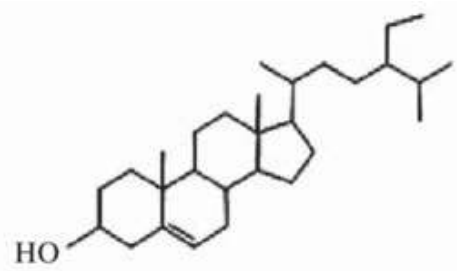

(a)

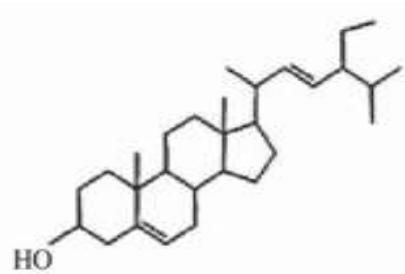

(b)

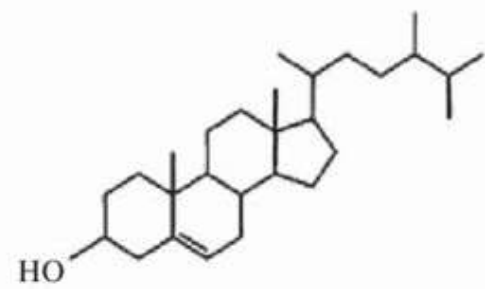

(c)

Figure 4. Major phytosterols in rice bran oil (Vaquero et al., 2010): (a) $\beta$-sitosterol; (b) stigmasterol; (c) campesterol. 
Table 8. Detection and quantification of phytosterol in rice bran and its oil

\begin{tabular}{|c|c|c|c|}
\hline Sample & Detection method & $\begin{array}{l}\begin{array}{l}\text { Concentration } \\
\text { sample })\end{array} \\
\text { sag } / 100 \mathrm{~g} \\
\end{array}$ & Reference \\
\hline Rice bran oil & RP-HPLC & $\begin{array}{l}\text { Stigmasterol: } 182-270 \\
\beta \text {-Sitosterol: } 1020-1270 \\
\text { Campesterol: } 400-490\end{array}$ & $\begin{array}{l}\text { (Balachandran et al., } \\
\text { 2008) }\end{array}$ \\
\hline Rice bran & GC-MS & $\begin{array}{l}\beta \text {-Sitosterol: } 128.00-133.07 \\
\text { Campesterol: } 69.61-75.68\end{array}$ & $\begin{array}{l}\text { (Derakhshan- } \\
\text { Honarparvar et al., } \\
\text { 2010) }\end{array}$ \\
\hline Rice bran oil & GC-FID & $\begin{array}{l}\text { Crude oil: } \\
\text { Stigmasterol: } 235-246 \\
\beta \text {-Sitosterol: } 839-846 \\
\text { Campesterol: } 281-292 \\
\text { Refined oil: } \\
\text { Stigmasterol: } 126-136 \\
\beta \text {-Sitosterol: } 520-576 \\
\text { Campesterol: } 164-193\end{array}$ & $\begin{array}{l}\text { (Sawadikiat \& } \\
\text { Hongsprabhas, 2014) }\end{array}$ \\
\hline Rice bran oil & GC-MS & $\begin{array}{l}\text { Stigmasterol: 177-205 } \\
\beta \text {-Sitosterol: 497-625 } \\
\text { Campesterol: 203-352 }\end{array}$ & (Mingyai et al., 2018) \\
\hline Rice bran oil & GC-MS & $\begin{array}{l}\text { Stigmasterol: } 221.2 \\
\beta \text {-Sitosterol: } 735.7 \\
\text { Campesterol: } 226.4\end{array}$ & (Yang, et al., 2019) \\
\hline
\end{tabular}

RP-HPLC: reverse-phase high-performance liquid chromatography; GC: gas chromatography; FID: flame ionization detector; MS: mass spectrometry. (Lagarda et al., 2006)

RBO has a balanced fatty acid composition for fatty acid composition compared to other vegetable oils, as it was detected to contain $22.53 \%$ SFA, $45.25 \%$ MUFA, and $31.45 \%$ PUFA in the current study. The dominant fatty acid found in RBO were palmitic acid, oleic acid, and linoleic acid. These results agreed with many studies (Akhter et al., 2016; Balachandran et al., 2008; Latha \& Nasirullah, 2014; Mas'ud et al., 2017). As the end product of solvent fractionation of RBO, the fatty composition of RBOS was similar to RBO. However, the relative abundance of SFA was observed to be higher in RBOS when compared to RBO. Besides, the unsaturated fatty acid was found to be lower in RBOS. The increasing of SFA content increased the melting point, made the RBOS exist in solid form. The primary fatty acids in CS were palmitic acid (51.49\%) and elaidic acid (34.31\%). These results were in agreement with those from the study of El-Gawad et al. (2015). As a product of partial 
hydrogenation of palm oil, CS has a similar fatty acid composition (Montoya et al., 2014), unless elaidic acid. Elaidic acid is the trans-isomer of oleic acid (Figure 5).

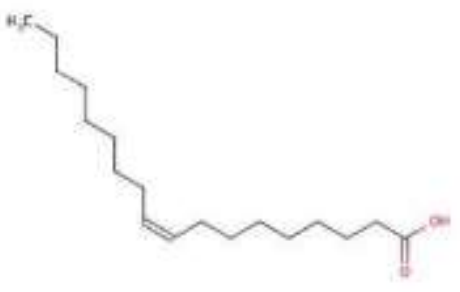

(a)

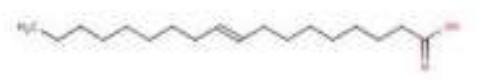

(b)

Figure 5. (a) oleic acid; (b) elaidic acid

RBO and RBOS were rich in MUFA and PUFA. MUFA helps to increase HDL cholesterol and reduce the probability of getting cardiovascular diseases. Diabetes mellitus can be controlled by reducing the glycosylated hemoglobin by MUFA (Salgado et al., 2019). PUFA has been associated with somebody's system functioning, such as cardiovascular, endocrine, immune, inflammatory, nervous, reproductive, respiratory, and others (Srikaeo, 2014). With their presence, cellular activities are affected, and membrane fluidity is altered. These will result in the modulation of enzymes, receptors, and transporters' actions (Srikaeo, 2014). In addition, $\alpha$-linoleic acid and linoleic acid are essential fatty acids since the human body cannot synthesize them but only can be taken from the human diet (Salgado et al., 2019). Albeit high SFA content in RBO compared to other vegetable oils, the unsaponifiable matter in RBO is also responsible for reducing cholesterol level (Chandrashekar et al., 2014; Zavoshy et al., 2012).

Table 9. Fatty acid composition of common vegetable oils.

\begin{tabular}{|c|c|c|c|c|}
\hline \multirow{2}{*}{ Oil type } & \multicolumn{3}{|c|}{ Fatty acid } & \multirow{2}{*}{ Reference } \\
\hline & SFA & MUFA & PUFA & \\
\hline Coconut oil & 92.1 & 6.2 & 1.6 & $\begin{array}{l}\text { (Orsavova et al., } \\
\text { 2015) }\end{array}$ \\
\hline Corn oil & $19.0-23.0$ & $19.0-50.0$ & $34.0-64.0$ & (List, 2016) \\
\hline Canola oil & 7.0 & $50.0-65.0$ & $6.0-14.0$ & $\begin{array}{l}\text { (Nandasiri et al., } \\
\text { 2020) }\end{array}$ \\
\hline Peanut oil & 10.7 & 71.1 & 18.2 & $\begin{array}{l}\text { (Orsavova et al., } \\
\text { 2015) }\end{array}$ \\
\hline Palm oil & $41.0-51.4$ & $27.2-50.0$ & $7.1-26.0$ & $\begin{array}{l}\text { (Montoya et al., } \\
\text { 2014) }\end{array}$ \\
\hline
\end{tabular}




\begin{tabular}{|c|c|c|c|c|}
\hline \multirow{2}{*}{ Oil type } & \multicolumn{3}{|c|}{ Fatty acid } & \multirow{2}{*}{ Reference } \\
\hline & SFA & MUFA & PUFA & \\
\hline Rapeseed oil & 6.3 & 72.8 & 20.9 & $\begin{array}{l}\text { (Orsavova et al., } \\
\text { 2015) }\end{array}$ \\
\hline Sunflower oil & 7.7-13.6 & $14.0-39.4$ & $48.3-74.0$ & (Akkaya, 2018) \\
\hline Soybean oil & $10.4-18.7$ & $17.7-26.1$ & $55.3-66.6$ & (List, 2016) \\
\hline Safflower oil & 9.3 & 11.6 & 79.1 & $\begin{array}{l}\text { (Orsavova et al., } \\
\text { 2015) }\end{array}$ \\
\hline Olive oil & $15.0-20.5$ & $58.8-72.4$ & $10.9-20.6$ & $\begin{array}{l}\text { (Riachy et al., } \\
\text { 2019) }\end{array}$ \\
\hline
\end{tabular}

SFA: saturated fatty acid; MUFA: monounsaturated fatty acid; PUFA: polyunsaturated fatty acid.

\subsection{Textural Properties}

Spreadability is an essential attribute of spreadable products like cream, butter, spread, margarine, and others. It is known as the pressure needed so that the spreadable products can be uniformly distributed over a surface (Bayarri et al., 2012). The difference in firmness and work of shear results in CS and RBOS were not significantly $(p>0.05)$ significant. The lower the firmness and work of shear, the more spreadable the product (Bayarri et al., 2012). Therefore, it is concluded that RBOS has demonstrated similar spreadability with CS. The fat crystal networks associated with the liquid oil phase bring to the spreadability, as the ratio of solid to liquid fat determines the consistency of spreads and shortening. Apart from solid fat content, the hardness of a spreadable product is also evaluated by crystal size and polymorphic behaviour (Glibowski et al., 2008). A spreadable product requires to fulfill a few criteria (Carr \& Vaisey-Genser, 2003). It must be able to stable and maintain its form at room temperature. Besides, it can spread quickly over a broad temperature range. Moreover, it must melt and release the flavor in the mouth in a short time without any gummy sensation (Carr \& Vaisey-Genser, 2003).

\subsection{Thermal Properties}

Both CS and RBOS have a broad melting temperature range, as they possess mixtures of triglyceride esters with varied unsaturation (Omar et al., 2017; Wang et al., 2017). CS, palm oil-based, has a melting point within the range of $34-44^{\circ} \mathrm{C}$ since palm oil has a higher melting point than other common vegetable oils (Lai et al., 2012). RBOS has a significantly $(p<0.05)$ lower melting point and enthalpy than CS due to significantly $(p<$ 0.05) lower SFA content. The lower the enthalpy, the lower energy required to melt RBOS compared to CS (Devi \& Khatkar, 2017). 
According to Devi and Khatkar (2017), the first endotherm region represented the melting process of $\alpha$ polymorph while the second endotherm region corresponds to the melting of $\beta^{\prime}$ polymorph. Besides, the melting of $\beta$ polymorph is represented by the last endotherm region. According to Dolatowska-Zebrowska et al. (2019), a smaller shoulder peak at the melting curve represents the melting of trans-configurated monounsaturated fatty acid and long-chain saturated fatty acid with carbon numbers 16 and above. On the contrary, the melting of unsaturated fatty acid and fatty acid with carbon numbers below 16 contributes to the large shoulder peak formation (Dolatowska-Zebrowska et al., 2019).

For the TGA test, the difference in onset and peak temperature results in both samples were not significant $(p>0.05)$ important. Both CS and RBOS have only single-phase decomposition. CS showed more excellent thermal stability than RBOS but not significantly $(p>0.05)$ different.

\section{Conclusions}

In the present study, RBOS contains a higher amount of bioactive compounds such as $\gamma$ oryzanol and phytosterols that indicate better physicochemical properties than CS. RBOS and RBO have balanced fatty acid compositions, which makes them beneficial and functional. RBOS has similar textural properties and decomposition temperature to CS. Although RBOS has a lower melting point than CS, it still stables at room temperature. The results of this study are a promising indication that RBOS could be a suitable option as an alternate shortening in bakery products.

Author Contributions: Conceptualization, Norazatul Hanim, M.R. and Eng, H. Y.; methodology, Eng, H. Y.; experimental and data analysis, Eng, H.Y. and Ilias, N. N.; writing - original draft preparation, Eng, H. Y.; writing — review and editing, Norazatul Hanim, M.R.

Funding: This work was funded by the Research University Grant (RUI) (1001.PTEKIND.8014086) of Universiti Sains Malaysia, Pulau Pinang.

Acknowledgments: The researchers would like to thank Universiti Sains Malaysia for providing funds for this work under Research University Grant (RUI) (1001.PTEKIND.8014086). The researchers would also like to thank all the lab assistants and postgraduate students of the Food Technology Division, Universiti Sains Malaysia, for assisting in using instruments and providing advice on lab works.

Conflicts of Interest: The authors declare no conflict of interest.

\section{References}

Akhter, M., Mahmood, A., Raza, M. A., et al. (2016). Free fatty acid profiling of rice bran oils for improving shelf life through parboiling and different treatments. Journal of Nutrition and Food Science, 6(1). doi:10.4172/2155-9600.1000449 
Akkaya, M. R. (2018). Fatty acid compositions of sunflowers (Helianthus annuus L.) grown in east Mediterranea region. Rivista Italiana Delle Sostanze Grasse XCV, 4, 239-247.

Bakota, E. L., Winkler-Moser, J. K., \& Liu, S. X. (2014). Evaluation of a rice bran oil-derived spread as a functional ingredient. European Journal of Lipid Science and Technology, 116(5), 521-531. doi:10.1002/ej1t.201300259

Bakota, E. L., Winkler-Moser, J. K., Hwang, H.-S., et al. (2013). Solvent fractionation of rice bran oil to produce a spreadable rice bran product. European Journal of Lipid Science Technology, 115, 847-857. doi:10.1002/ejlt.201200355

Balachandran, C., Maymol, P. N., Thomas, S., et al. (2008). An eco-friendly approach to process rice bran for high quality rice bran oil using supercritical carbon dioxide for nutraceutical applications. Bioresource Technology, 99, 2905-2912. doi:10.1016/j.biortech.2007.06.004

Bayarri, S., Carbonell, I., Costell, E. (2012). Viscoelasticity and texture of spreadable cheeses with different fat contents at refrigeration and room temperatures. Journal of Dairy Science, 95, 6926-6936. doi:10.3168/jds.2012-5711

Bhatnagar, A. S., Prabhakar, D. S., Prasanth Kumar, P. K., et al. (2014). Processing of commercial rice bran for the production of fat and nutraceutical rich rice broken, rice germ and pure bran. LWT - Food Science and Technology, 58(1), 306-311. doi:10.1016/j.lwt.2014.03.011

Bouarroudj, K., Tamedjari, A., Larbat, R. (2016). Quality, composition and antioxidant activity of Algerian wild olive (Olea europaea L. subsp. Oleaster) oil. Industrial Crops and Products, 83, 484-491. doi:10.1016/j.indcrop.2015.12.081

Bussing, K. (2019). The Difference Between Butter, Margarine, Shortening and Lard. Retrieved from Taste of Home: https://www.tasteofhome.com/article/the-difference-between-butter-margarine-shorteningand-lard/

Carr, R. A., Vaisey-Genser, M. (2003). Margarine: Methods of manufacture. In L. Trugo, \& P. M. Finglas, Encyclopedia of Food Science and Nutrition (pp. 3709-3714). Academic Press.

Chandrashekar, P., Kumar, P. P., Ramesh, H. P., et al. (2014). Hypolipidemic effect of oryzanol concentrate and low temperature extracted crude rice bran oil in experimental male wistar rats. Journal of Food Science and Technology, 51(7), 1278-1285. doi:10.1007/s13197-012-0628-9

Derakhshan-Honarparvar, M., Hamedi, M. M., Pirouzifard, M. K. (2010). Rice bran phytosterols of three widespread Iranian cultivars. Journal of Agricultural Science and Technology, 12, 167-172.

Devi, A., Khatkar, B. S. (2017). Thermal-physical properties of fats and oils. International Journal of Engineering and Technical Research, 7(2), 45-50.

Dolatowska-Zebrowska, K., Ostrowska-Lige,za, E., Wirkowska-Wojdyła, M., et al. (2019). Characterization of thermal properties of goat milk fat and goat milk chocolate by using DSC, PDSC and TGA methods. Journal of Thermal Analysis and Calorimetry, 138, 2769-2779. doi:10.1007/s10973-019-08181-0 
Francisqueti, F. V., Ferron, A. J., Hasimoto, F. K., et al. (2018). Gamma oryzanol treats obesity-induced kidney injuries by modulating the adiponectin receptor 2/PPAR- $\alpha$ axis. Oxidative Medicine and Cellular Longevity, 2018. doi:10.1155/2018/1278392

Ghosh, M. (2007). Reviews on recent trends in rice bran oil processing. Journal of the American Oil Chemists' Society, 84, 315-324.

Glibowski, P., Zarzycki, P., Krzepkowska, M. (2008). The rheological and instrumental textural properties of selected table fats. International Journal of Food Properties, 11(3), 678-686.

Hasibuan, V. R., Aini, N., Febriyanti, et al. (2018). The effect of additional detergent in crude palm oil in the process of separation stearin. IOP Conference Series: Journal of Physics, 970, 1-5. doi:10.1088/1742$6596 / 970 / 1 / 012020$

Heidtmann-Bemvenuti, R., Nora, N. S., Badiale-Furlong, E. (2012). Extraction of $\gamma$-oryzanol from rice bran. Ciência e Agrotecnologia, 36(6), 665-673.

Iqbal, M. P. (2014). Trans-fatty acids - A risk factor for cardiovasuclar disease. Pakistan Journal of Medical Science, 30(1), 194-197. doi:10.12669/pjms.301.4525

Jääskeläinen, A.-S., Liitiä, T., Mikkelson, A., et al. (2017). Aqueous organic solvent fractionation as means to improve lignin homogenity and purity. Industrial Crops and Products, 103, 51-58. doi:10.1016/j.indcrop.2017.03.039

Jones, T. (2016). Shortening: Good or bad? Retrieved from Healthline: https://www.healthline.com/nutrition/shortening

Kellens, M., Gibon, V., Hendrix, M., et al. (2007). Palm oil fractionation. European Journal of Lipid Science and Technology, 109(4), 336-349. doi:10.1002/ejlt.200600309

Khatoon, S., Gopalakrishna, A. G. (2004). Fat-soluble nutraceuticals and fatty acid composition of selected Indian rice varieties. Journal of American Oil Chemists' Society, 81(10), 939-943.

Konukan, D. B., Arslan, M., Oksuz, A. (2019). Physicochemical properties of cold pressed sunflower, peanut, rapeseed, mustard and olive oils grown in the Eastern Mediterranean region. Saudi Journal of Biological Sciences, 26(2), 340-344. doi:10.1016/j.sjbs.2018.04.005

Lagarda, M. J., Garc'ia-Llatas, G., Farre', R. (2006). Analysis of phytosterols in foods. Journal of Pharmaceutical and Biomedical Analysis, 41, 1486-1496. doi:10.1016/j.jpba.2006.02.052

Lai, O.-M., Jacoby, J. J., Leong, W.-F., et al. (2019). Nutritional studies of rice bran oil. In L.-Z. Cheong, \& X. Xu, Rice Bran and Rice Bran Oil (pp. 19-54). Academic Press and AOCS Press.

Lai, O.-M., Lo, S.-K., Akoh, C. C. (2012). Enzymatic and chemical modification of palm oil, palm kernel oil, and its fractions. In O.-M. Lai, C.-P. Tan, C. C. Akoh, Palm oil: Production, processing, characterization, and uses (pp. 527-543). Academic Press and AOCS Press.

Latha, R. B., Nasirullah, D. R. (2014). Physico-chemical changes in rice bran oil during heating at frying temperature. Journal of Food Science Technology, 51(2), 335-340. doi:10.1007/s13197-011-0495-9 
Lee, J. H., Yu, F., Choi, M. S., et al. Compositional study on rice bran oil after lipase-catalyzed glycerolysis and solvent fractionations. Journal of Food Science, 72(3), 163-167. doi:10.1111/j.17503841.2007.00299.x

Lin, Y., Koppenol, W. P., Knol, D., et al. (2019). Serum concentration of plant sterol oxidation products (POP) compared to cholesterol oxidation products (COP) after intake of oxidized plant sterols: A randomised, placebo-controlled, double-blind dose-response pilot study. Nutrients, 11(10), 2319-2331. doi:10.3390/nu11102319

List, G. R. (2016). Oilseed composition and modification for health and nutrition. In T. A. Sanders, Functional Dietary Lipids: Food formulation, consumer issues and innovation for health (pp. 23-46). Woodhead Publishing.

Mariod, A., Ismail, M., Abd Rahman, N., et al. (2014). Stability of rice bran oil extracted by SFE and soxhlet methods during accelerated shelf-life storage. Grasas y Aceites, 65(1), 1-10.

Mas'ud, F., Mahendradatta, M., Laga, A., et al. (2017). Component, fatty acid and mineral composition of rice bran oil extracted by multistage with hexane and ethanol. International Journal of Scientific and Technology Research, 6(11), 63-69.

Mingyai, S., Srikaeo, K., Kettawan, A., et al. (2018). Effects of extraction methods on phytochemicals of rice bran oils produced from colored rice. Journal of Oleo Science, 67(2), 135-142.

Montoya, C., Cochard, B., Flori, A., et al. (2014). Genetic achitecture of palm oil fatty acid composition in cultivated oil palm (Elaeis guineensis Jacq.) compared to its wild relative E. oleifera (H.B.K) Cortés. PLOS ONE, 9(5). doi:10.1371/journal.pone.0095412

Nagendra Prasad, M., Sanjay, K., Shravya, K. M., et al. (2011). Health benefits of rice bran - A review. Journal of Nutrition and Food Science, 1(3), 108-115. doi:10.4172/2155-9600.1000108

Nandasiri, R., Michael Eskin, N. A., Eck, P., et al. (2020). Application of green technology on extraction of phenolic compounds in oilseeds (canola). In M. F. Ramadan, Cold pressed oils: Green technology, bioactive compounds, functionality, and applications (pp. 81-96). United State: Academic Press.

Omar, K. A., Gounga, M. E., Liu, R., et al. (2017). Triacylglycerol composition, melting and crystallization profiles of lipase catalysed anhydrous milk fats hydrolysed. International Journal of Food Properties, 20(S2), 1230-1245. doi:10.1080/10942912.2017.1301954

Orsavova, J., Misurcova, L., Ambrozova, J. V., et al. (2015). Fatty acids composition of vegetable oils and its contribution to dietary energy intake and dependence of cardiovascular mortality on dietary intake of fatty acids. International Journal of Molecular Science, 16(6), 12871-12890. doi:10.3390/ijms160612871

Özdestan, Ö., Erol, T., Acar, B. (2014). Phytosterols in rice bran and the usage of rice bran in food industry. Foodbalt (pp. 24-27). Jelgava: Drukātava.

Panchal, S. S., Patidar, R. K., Jha, A. B., et al. (2017). Anti-Inflammatory and Antioxidative Stress Effects of Oryzanol in Glaucomatous Rabbits. Journal of Ophthalmology, 2017, 9. doi:10.1155/2017/1468716 
Patel, M., Naik, S. N. (2004). Gamma-Oryzanol from rice bran oil-A review. Journal of Scientific and Industrial Research, 63(7), 569-578.

Plante, M., Crafts, C., Bailey, B., et al. (2011). Simple and Direct Analysis of Phytosterols by Reversed-Phase HPLC and Charged Aerosol Detection. Planta Medica, 77(12), 1-4. doi:10.1055/s-0031-1282198

Pungseeklao, T., Opanasopit, P., Khuwijitjaru1, P. (2016). Development of a method for quantitative determination of oryzanol using near infrared spectroscopy. Food and Applied Bioscience Journal, $4(2), 107-115$.

Riachy, M. E., Hamade, A., Ayoub, R., et al. (2019). Oil content, fatty acid and phenolic profiles of some olive varieties growing in Lebanon. Frontiers in Nutrition. doi:https://doi.org/10.3389/fnut.2019.00094

Sahu, S., Ghosh, M., Bhattacharyya, D. K. (2018). Isolation of the unsaponifiable matter (squalene, phytosterols, tocopherols, oryzanol andfatty alcohols) from a fatty acid distillate of rice bran oil. Grasas y Aceites, 262-270. doi:10.3989/gya.1112172

Salgado, P. R., Giorgio, L. D., Musso, Y. S., et al. (2019). Bioactive packaging: Combining nanotechnologies with packaging for improved food functionality. In A. L. Rubio, M. J. Rovira, M. m. Sanz, \& L. G. Gómez-Mascaraque, Nanomaterials for food application (pp. 233-270). Elsevier.

Sawadikiat, P., Hongsprabhas, P. (2014). Phytosterols and $\gamma$ - oryzanol in rice bran oils and distillates from physical refining process. International Journal of Food Science and Technology, 49(9), 2030-2036. doi:10.1111/ijfs.12506

Shafie, N. H., Norhaizan, M. (2017). The healing components of rice bran. In A. Ismail, \& A. Azlan, Functional Foods: Wonder of the World (pp. 341-368). Selangor, Malaysia: Universiti Putra Malaysia.

Shaik, R., Aparna, K., Azam, M. M., et al. (2018). Effect of rice bran oil spread (RBOS) as a fat substitute on the sensory properties of baked goods. Journal of Oilseeds Research, 35(1), 51-56.

Singh, P. (2018). Physico-chemical investigations of mustard seed (Brassica juncea L.). International Journal of Scientific Research in Multidisciplinary Studies, 4(6).

Srikaeo, K. (2014). Organic Rice Bran Oils in Health. In R. R. Watson, V. R. Preedy, \& S. Zibadi, Wheat and Rice in Disease Prevention and Health (pp. 453-465). United State: Academic Press.

Textron. (2011). Olive oil, organic extra virgin . Retrieved from Textron: https://www.brenntag.com/media/documents/bsi/product-data-sheets/lifescience/textron_natural_oils/olive_oil_organic_tx008075_pds.pdf

Tolve, R., Cela, N., Condelli, N., et al. (2020). Microencapsulation as a tool for the formulation of functional foods: The phytosterols' case study. Foods, 9(4), 470-459. doi:10.3390/foods9040470

Vaquero, M. P., Sánchez Muniz, F. J., Redondo, S. J., et al. (2010). Major diet-drug interactions affecting the kinetic characteristics and hypolipidaemic properties of statins. Nutricion hospitalaria: organo oficial de la Sociedad Espanola de Nutricion Parenteral y Enteral, 25(2), 193-206. doi:10.3305/nh.2010.25.2.4405 
Vissers, M. N., Zock, P. L., Meijer, G. W., et al. (2000). Effect of plant sterols from rice bran oil and triterpene alcohols from sheanut oil on serum lipoprotein concentrations in humans. American Journal of Clinical Nutrition, 72(6), 1510-1515.

Wang, O., Liu, J., Cheng, Q., et al. (2015). Effects of ferulic acid and $\gamma$-oryzanol on high-fat and high-fructose diet-induced metabolic syndrome in rats. Plos One, 10(2). doi:10.1371/journal.pone.0118135

Wang, T., Hicks, K. B., Moreau, R. (2002). Antioxidant activity of phytosterols, oryzanol and phytosterol conjugates. Journal of the American Oil Chemists' Society, 79, 1201-1206.

Wang, Y., Li, Y., Han, J., et al. (2017). Effect of melting point on the physical properties of anhydrous milk fat. IOP Conf. Series: Materials Science and Engineering, 274, 1-7. doi:10.1088/1757$899 X / 274 / 1 / 012072$

Wong, W.-T., Ismail, M., Iman, M. U., et al. (2016). Modulation of platelet functions by crude rice (Oryza sativa) bran policosanol extract. BMC Complementary Medicine and Therapies, 16(252). doi:10.1186/s12906-016-1223-9

Xu, Z., Godber, J. S. (2001). Antioxidant activities of major components of $\gamma$-oryzanol from rice bran using a linoleic acid model. Journal of the American Oil Chemists' Society, 78(6), 645-649.

Yang, R., Xue, L., Zhang, L., et al. (2019). Phytosterol contents of edible oils and their contributions to estimated phytosterol intake in the Chinese diet. Foods, 8(8), 334-346. doi:10.3390/foods8080334

Yu, F., Kim, S. H., Kim, N.-S., et al. (2006). Composition of solvent-fractionated rice bran oil. Journal of Food Lipids, 13(3), 286-297. doi:10.1111/j.1745-4522.2006.00052.x

Zahran, H. A., Tawfeuk, H. Z. (2019). Physicochemical properties of new peanut (Arachis hypogaea L.) varieties. Oilseeds \& fats Crops and Lipids (OCL), 26(19), 1-7. doi:10.1051/ocl/2019018

Zaliha, O., Chong, C. L., Cheow, C. S., et al. (2004). Crystallization properties of palm oil by dry fractionation. Food Chemistry, 86(2), 245-250. doi:10.1016/j.foodchem.2003.09.032

Zavoshy, R., Noroozi, M., Jahanihashemi, H. (2012). Effect of low calorie diet with rice bran oil on cardiovascular risk factors in hyperlipidemic patients. Journal of Research in Medical Sciences, 17(7), 626-631.

Attribution-NonCommercial 4.0 International License (CC-BY-NC4.0) 